\title{
Analisis Angka Asam pada Minyak Goreng dan Minyak Zaitun
}

\author{
Analysis of Acid Numbers in Cooking Oil and Olive Oil \\ Ardhista Shabrina Fitri ${ }^{1}$, Yolla Arinda Nur Fitriana ${ }^{2}$ \\ ${ }^{I}$ Farmasi - Universitas Muhammadiyah Purwokerto, Indonesia \\ ${ }^{2}$ Teknologi Pangan - Universitas Ahmad Dahlan Yogyakarta, Indonesia \\ 12ardhista.fitri@ump.ac.id \\ ²yolla.anf@gmail.com
}

\begin{abstract}
ABSTRAK
Minyak merupakan salah satu zat makanan yang penting sebagai sumber energi bagi kebutuhan tubuh manusia. Minyak nabati mengandung asam lemak tak jenuh dan beberapa asam lemak esensial seperti asam oleat, linoleat, dan linolenat. Jenis minyak yang banyak dikonsumsi masyarakat adalah minyak goreng (minyak kelapa) dan minyak zaitun. Untuk menjaga kadar gizi sebagai bahan makanan, minyak goreng dan minyak zaitun perlu diketahui kandungan asam lemak dalam hal ini ditunjukkan dengan bilangan asam. Hasil percobaan menunjukkan bahwa angka asam yang didapatkan dari sampel minyak goreng adalah 0.647 , sedangkan dari sampel olive oil didapatkan angka sebesar 3.194. Dari perhitungan tersebut, dapat dinyatakan bahwa bilangan asam olive oil melebihi ambang batas bilangan asam berdasarkan SNI-3741-2013 tentang standar mutu minyak goreng yaitu maksimal sebesar $0.6 \mathrm{mg} \mathrm{KOH} / g r a m$, sedangkan minyak goreng sesuai dengan ambang batas bilangan asam.
\end{abstract}

Kata-kata kunci: minyak goreng, minyak zaitun, angka asam, ambang batas.

\begin{abstract}
Oil is one of the important food substances as a source of energy for the needs of the human body. Vegetable oil contains unsaturated fatty acids and several essential fatty acids such as oleic acid, linoleic acid, and linolenic acid. The types of oil that are consumed by many people are cooking oil (coconut oil) and olive oil. To maintain nutrient levels as a food ingredient, cooking oil and olive oil need to know the content of fatty acids in this case indicated by the acid number. The experimental results show that the acid number obtained from the cooking oil sample was 0.647, while the olive oil sample obtained a figure of 3,194. From these calculations, it can be stated that the olive oil acid number exceeds the threshold of the acid number based on SNI-3741-2013 regarding cooking oil quality standards that is a maximum of $0.6 \mathrm{mg} \mathrm{KOH} / \mathrm{gram}$, while cooking oil is in accordance with the acid number threshold.
\end{abstract}

Key words: cooking oil, olive oil, sour numbers, threshold.

\section{PENDAHULUAN}

Minyak merupakan salah satu zat makanan yang penting bagi kebutuhan tubuh manusia. Selain itu minyak juga merupakan sumber energy dimana satu gram minyak dapat menghasilkan 9 kkal (Winarno, 2002). Minyak (nabati) mengandung asam lemak 
tak jenuh dan beberapa asam lemak esensial seperti asam oleat, linoleat, linolenat (Ketaren, 1986).

Minyak goreng merupakan bahan pangan yang paling banyak digunakan oleh masyarakat dalam memasak makanan terutama untuk menggoreng. Minyak goreng adalah lemak yang berbentuk cair pada suhu kamar. Minyak goreng merupakan bahan pangan dengan komposisi utama trigliserida yang berasal dari bahan nabati, dengan atau tanpa perubahan kimiawi dan telah melalui proses rafinasi atau pemurnian yang digunakan untuk menggoreng (Chatzilazarou et al., 2006). Selain minyak goreng sebagai bahan utama proses menggoreng, minyak zaitun juga digunakan oleh sebagian orang. Minyak zaitun adalah minyak alami yang diekstrasi dari buah zaitun. Sekitar 24 persen minyak zaitun terdiri dari lemak jenuh, omega 6 , dan asam lemak omega 3 . Namun asam lemak terbanyak di dalam minyak zaitun adalah asam oleat yang sangat sehat. Asam oleat ini diyakini dapat membantu mengurangi peradangan (Adrian, 2018).

Kandungan asam lemak bebas dalam minyak yang bermutu baik hanya terdapat dalam jumlah kecil, sebagian besar asam lemak terikat dalam bentuk ester atau bentuk trigliserida. Minyak kelapa dapat mengalami perubahan aroma dan cita rasa selama penyimpanan. Perubahan ini disertai dengan terbentuknya senyawa-senyawa yang dapat menyebabkan kerusakan minyak (Ketaren, 1986).

Bilangan asam menunjukkan banyaknya asam lemak bebas dalam minyak dan dinyatakan dengan $\mathrm{mg}$ basa per 1 gram minyak. Bilangan asam juga merupakan parameter penting dalam menentukan kualitas minyak. Bilamgan ini menunjukkan banyaknya asam lemak bebas yang ada dalam minyak akibat terjadi reaksi hidrolisis pada minyak terutama pada saat terjadi pengolahan. Asam lemak merupakan struktur kerangka dasar untuk kebanyakan bahan lipid (Agoes, 2008).

Bilangan asam didefinisikan sebagai jumlah $\mathrm{KOH}$ yang diperlukan untuk menetralkan asam lemak bebas yang terdapat dalam 1 gram minyak. Dimana angka asam iini menunjukkan banyaknya asam lemak bebas yang terdapat dalam suatu lemak atau minyak (Page, 1997). Bilangan asam lemak yang bebas menunjukkan asam lemak bebas yang besar pula, yang berasal dari hidrolisa minyak atau lemak, ataupun karena proses pengolahan yang kurang baik. Makin tinggi bilangan asam, maka makin rendah kualitas (Sudarmadji and Bambang, 2003).

Berdasarkan uraian tersebut, dalam penelitian ini dilakukan percobaan untuk mengetahui rerata angka asam pada sampel minyak goreng dan olive oil (minyak zaitun).

\section{METODE}

\section{A. Alat dan Bahan}

Alat yang digunakan dalam praktikum ini adalah timbangan digital, Erlenmeyer $250 \mathrm{ml}$, pipet ukur $10 \mathrm{ml}$, propipet merah, buret dan statif, gelas ukur $100 \mathrm{ml}$, stopwatch, shaker waterbath, pipet tetes, dan serbet.

Bahan yang digunakan dalam praktikum ini adalah sampel minyak goreng Bimoli, sampel olive oil (minyak zaitun), indicator phenophtalein, akuades, KOH $0.1 \mathrm{~N}$, etanol 95\%, aluminium foil, tisu, dan kertas label.

\section{B. Prosedur Percobaan}

Percobaan ini dilakukan menggunakan langkah-langkah seperti pada Gambar 1. 


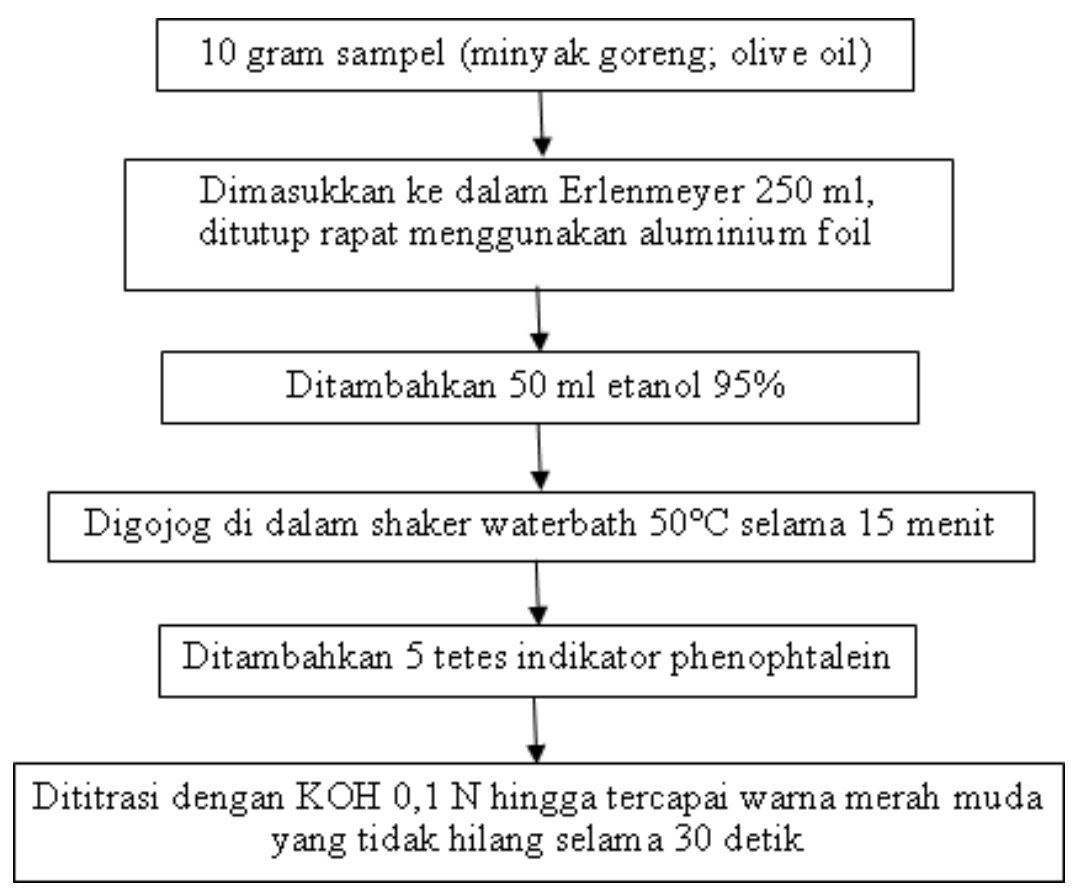

Gambar 1. Langkah percobaan analisis angka asam

\section{HASIL DAN PEMBAHASAN}

Percobaan ini dilakukan dengan tiga kali ulangan dengan masing-masing volume $\mathrm{KOH}$ sebagai berikut:

- Banyak volume KOH tiap ulangan percobaan pada sampel minyak goreng adalah sebesar 1,3 ml, 1,1 ml, dan 1,1 ml.

- Banyak volume $\mathrm{KOH}$ tiap ulangan percobaan pada sampel olive oil adalah 6,3 ml, 5,8 $\mathrm{ml}$, dan $5,3 \mathrm{ml}$.

Hasil percobaan tersaji pada Tabel 1.

Tabel 1. Perolehan angka asam pada minyak goreng dan minyak zaitun

\begin{tabular}{ccccc}
\hline Sampel & Ulangan & Volume KOH & Angka Asam & Rerata \\
\hline \multirow{2}{*}{ Minyak } & 1 & $1,3 \mathrm{ml}$ & 0.708 & \\
Goreng & 2 & $1,1 \mathrm{ml}$ & 0.617 & 0.647 \\
& 3 & $1,1 \mathrm{ml}$ & 0.617 & \\
\multirow{2}{*}{ Olive Oil } & 1 & $6,3 \mathrm{ml}$ & 3.354 & \\
& 2 & $5,8 \mathrm{ml}$ & 3.254 & 3.194 \\
\hline
\end{tabular}

Bilangan asam adalah bilangan yang menunjukkan jumlah asam lemak bebas yang terkandung dalam lemak atau minyak, yang biasanya dihubungkan dengan proses hidrolisis lemak atau minyak. Hidrolisis lemak atau minyak oleh air dengan katalis enzim atau panas pada ikatan trigliserida akan menghasilkan asam lemak bebas. Prinsip analisis angka asam ini adalah sejumlah tertentu sampel yang mengandung lemak dilarutkan dalam alcohol netral kemudian dipanaskan sampai larut. Sampel yang telah larut tersebut dititrasi menggunakan basa alkali yang konsentrasinya telah diketahui untuk dihitung bilangan asamnya.

Pada percobaan ini, sampel sebanyak 10 gram direaksikan dengan ethanol 95\%. Fungsi penambahan alcohol adalah untuk melarutkan minyak. Selanjutnya sampel dipanaskan selama 15 menit pada suhu $50^{\circ} \mathrm{C}$, kemudian ditambahkan indikator 
phenophtalein sebelum dilakukan titrasi dengan $\mathrm{KOH} 0.1 \mathrm{~N}$. fungsi penambahan indicator $\mathrm{pp}$ adalah karena sampel dititrasi dengan larutan basa. Sedangkan fungsi penambahan $\mathrm{KOH}$ adalah untuk menetralkan asam lemak bebas yang terdapat dalam 1 gram minyak atau lemak. Indikator yang digunakan akan berubah menjadi merah muda bila suasana basa dan tetap ]bening jika dalam suasana asam. Titik akhir adalah waktu ketika proses titrasi dihentikan karena suasana telah menjai netral yang dilanjutkan oleh perubahan warna oleh indikator

Dari percobaan, angka asam yang didapatkan dari sampel minyak goreng adalah 0.647, sedangkan dari sampel olive oil didapatkan angka sebesar 3.194. Dari perhitungan tersebut, dapat dinyatakan bahwa bilangan asam olive oil melebihi ambang batas bilangan asam berdasarkan SNI-3741-2013 tentang standar mutu minyak goreng yaitu maksimal sebesar $0.6 \mathrm{mg} \mathrm{KOH/gram}$. Sedangkan minyak goreng sesuai dengan ambang batas bilangan asam. Hal ini berarti olive oil mungkin telah teroksidasi dan terhidrolisis..

Minyak goreng berfungsi sebagai penghantar panas, penambah rasa gurih, dan penambah nilai kalori bahan pangan. Semua minyak goreng tersusun atas unit-unit asam lemak dimana jumlah asam lemak alami yang telah diketahui ada dua puluh jenis asam lemak yang berbeda. Tidak satupun minyak goreng yang tersusun atas satu jenis asam lemak karena selalu dalam bentuk campuran dari berbagai asam lemak. Proporsi campuran ini menyebabkan minyak goreng berbentuk cair, bersifat sehat atau membahayakan kesehatan, bersifat netral, tahan simpan atau mudah tengik (Winarno, 2002).

Dalam 100 mililiter minyak zaitun terkandung total 884 kalori (44\% AKG harian) dan total lemak 100 gram, yang dapat mencukupi 153\% kebutuhan lemak harian tubuh. Namun sebagian besar kandungan lemak ini merupakan asam lemak tak jenuh tunggal, yang merupakan lemak baik. Minyak zaitun juga diperkaya oleh $15 \mathrm{mg}$ vitamin E yang mencukupi $72 \%$ kebutuhan harian tubuh, serta $61 \mathrm{mg}$ vitamin $\mathrm{K}$ yang mampu mencukupi 75 persen kebutuhan harian tubuh. Minyak zaitun sama sekali tidak mengandung kolesterol, karbohidrat, dan lemak (Wijaya, 2017).

Minyak zaitun memiliki berbagai macam manfaat bagi kesehatan, diantaranya dapat menurunkan kadar kolesterol buruk (LDL), mencegah penyakit jantung, membantu mengontrol tekanan darah, mencegah kanker, mencegah stroke, dan membantu mencegah obesitas (Adrian, 2018).

\section{KESIMPULAN}

Kesimpulan dari percobaan ini adalah:

- Rerata angka asam pada sampel minyak goreng adalah $0.647 \mathrm{mg} \mathrm{KOH/gram,} \mathrm{masih}$ memenuhi ambang batas mutu.

- Rerata angka asam pada sampel olive oil adalah $3.194 \mathrm{mg} \mathrm{KOH/gram} \mathrm{dan} \mathrm{tidak}$ memenuhi ambang batas (jauh melebihi ambang batas) mutu.

\section{DAFTAR PUSTAKA}

Adrian, K., 2018. Manfaat Minyak Zaitun untuk Kesehatan. Available at: https://www.alodokter.com/manfaat-minyak-zaitun-untuk-kesehatan [Accessed September 5, 2019].

Agoes, G., 2008. Pengembangan sediaan farmasi edisi revisi dan perluasan, Bandung: ITB.

Chatzilazarou, A., Gortzi, O., Lalas, S., Zoidis, E. and Tsaknis, J., 2006. Physicochemical changes of olive oil and selected vegetable oils during frying. Journal of Food Lipids, 13(1), pp.27-35. 
Ketaren, S., 1986. Pengantar Teknologi Minyak dan Lemak Pangan, Jakarta: UIPress.

Page, D.S., 1997. Prinsip-Prinsip Biokimia edisi ke-2. R. Soendoro, ed., Surabaya: Erlangga.

Sudarmadji, S. and Bambang, H., 2003. Prosedur analisa bahan makanan dan pertanian, Yogyakarta: Liberty.

Wijaya, H., 2017. Mana yang Lebih Sehat: Minyak Zaitun Biasa Atau Extra Virgin Olive Oil? Available at: https://hellosehat.com/hidup-sehat/fakta-unik/beda-minyakzaitun-extra-virgin-olive-oil/ [Accessed September 3. 2019].

Winarno, F.G., 2002. Kimia pangan dan gizi, Jakarta: Gramedia Pustaka Utama. 